\title{
Morphological characteristics of soybean root apexes as indicators of soil compaction
}

\author{
Julio César Ramos ${ }^{1 *}$; Silvia Del Carmen Imhoff²; Miguel Ángel Pilatti²; Abelardo Carlos \\ Vegetti ${ }^{1}$ \\ ${ }_{2}^{1} U N L / F C A$ - Depto. de Biología, Kreder 2805, S3080HOF - Esperanza, Santa Fe - Argentina.

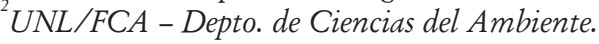 \\ *Corresponding author <jramos@fca.unl.edu.ar>
}

\begin{abstract}
Plant soil compaction poses a serious problem to agriculture because it produces different types of changes in plant characteristics. No method has been implemented to date to use root morphological changes as indicators of soil compaction levels. Therefore, the aim of the present study was to evaluate whether or not the morphological changes in root apexes of soybean (Glycine max (L.) Merrill) can be used as indicators of soil compaction levels. To this end, a silt-loamy soil material (from a Typic Argiudoll, Esperanza series), sieved through a $2 \mathrm{~mm}$ mesh was used and the following soil bulk density levels were determined: 1.1, 1.3 and $1.5 \mathrm{~g} \mathrm{~cm}^{-3}$ for which the corresponding mechanical resistances were $<0.1,0.5$ and $3.5 \mathrm{MPa}$, respectively. The distance from the apex to the first tertiary root and the root diameter at $1.5 \mathrm{~cm}$ from the apex were measured on the secondary root apexes. A form factor equal to the quotient between these two variables was subsequently calculated. An inverse relationship between soil mechanical impedance and secondary root length and form factor as well as a direct relationship with the secondary root diameter were observed. Changes in rhizodermis cells were also recorded. The following morphological characteristics were found to evidence the highest sensitivity to soil compaction: i) the form factor, ii) rhizodermis papillose cells, iii) apical malformations in root hairs, and iv) root diameter in expansion areas. Taken together, the morphological characteristics of root apexes could be considered to be indicative of soil compaction.
\end{abstract}

Key words: Glycine max, mechanical impedance, root indicator, root hairs

\section{Características morfológicas de ápices de raízes de soja como indicadores de compactação do solo}

\begin{abstract}
RESUMO: A compactação do solo causa severos problemas devido a que gera diferentes mudanças nas características das plantas. Não existem métodos que possibilitem o uso das mudanças da morfologia das raízes como indicadores de níveis de compactação do solo. Avaliaram-se se alterações morfológicas nos ápices de soja podem ser utilizadas como indicadores de graus de compactação do solo. Solo peneirado a $2 \mathrm{~mm}$, classificado como Typic Argiudol (série Esperanza), foi compactado até atingir os seguintes valores de densidade do solo: 1.1, 1.3 e $1.5 \mathrm{~g} \mathrm{~cm}^{-3}$, para os quais corresponderam os valores de resistência mecânica de $<0.1,0.5$ e $3.5 \mathrm{MPa}$, respectivamente. A distância desde o ápice até a primeira raiz terciária e o diâmetro a $1.5 \mathrm{~cm}$ desde o ápice foram medidos nas raízes secundarias. Um fator de forma foi calculado fazendo o quociente entre as duas variáveis medidas. Houve uma relação inversa entre o cumprimento da raiz secundaria e fator de forma com a resistência mecânica, e uma relação direta entre esta ultima e o diâmetro das raízes secundárias. Alterações nas células da rizoderme foram determinadas. As seguintes características morfológicas se mostraram muito sensíveis a compactação do solo: i) o fator de forma, ii) as células papilosas da rizoderme, iii) malformações apicais nos pelos das raízes, e iv) diâmetro das raízes em áreas de expansão. As características morfológicas dos ápices das raízes podem ser consideradas indicadores de compactação dos solos.

Palavras-chave: Glycine max, resistência mecânica, pelos radiculares, raiz como indicador
\end{abstract}

\section{Introduction}

Several studies have been carried out on the morphological and physiological changes in roots growing in compact soil layers (Bengouh et al., 1993; Lynch, 1995; Montagu et al., 2001). In roots growing in compacted soils these changes have negative effects on the aerial part of plants because they reduce both the expansion foliar rate and stomatic conductance (Letey, 1985; Beemster and Masle, 1996; Bingham and Bengough, 2003; Young, et al., 1997). No method has been implemented to date to use root morphological changes as indicators of soil compaction levels.

Usually, soils exhibit cracks among aggregates or structural units. On account of the fact that roots preferably grow in cracks (Dardanelli et al., 2004), both the type and size of soil structural units are key to the distribution of roots (Logdson et al., 1987; Scholefield and Hall, 1985). During root growth, soil mechanical resistance alters tissue expansion (Bengough et al. 1993; Bengough et al., 2006) and cell division mechanisms (Croser et al., 1999). Interestingly, roots of either short

Sci. Agric. (Piracicaba, Braz.), v.67, n.6, p.707-712, November/December 2010 
or long diameter are generally found in compacted soils (Croser et al., 1999; Konôpka et al., 2009). Root widening occurs as a result of the radial expansion of cortical parenchymal cells rather than as a consequence of the emergence of new cell files in the cortex (Atwell, 1989; Croser et al., 2000). Soil compaction induces changes in the morphology of absorbent hairs and F-actin cytoskeleton (Alessa and Earnhart, 2000), both of which are crucial to root hair functioning (Dolan and Davies, 2004). Because soil mechanical resistance affects root cell expansion (Bengough et al., 2006) as well as root cell growth and root form (Goodman and Ennos, 1999), roots growing in compacted soils have a characteristic form. Therefore, we hypothesise that root length and diameter are direct indicators of the degree of soil compaction.

The root morphological characteristics can be easily measured either with free software such as Rootedge (Kaspar and Ewing, 1997), Rootfly (Clemson University, 2008), image analysers or with more sophisticated, licensed software such as WinRhizo (Regent Instruments, 2000) analyser. Furthermore, root length and root diameter have the advantage of showing directly the effect of soil compaction on roots. In view of this, the aim of the present study was to evaluate whether or not the morphological changes in soybean (Glycine max (L.) Merrill) root apexes could be considered as indicators of soil compaction levels.

\section{Material and Methods}

Soybean seeds (cultivar RA 518) were sterilized superficially in $0.05 \%$ sodium hypochlorite solution for 10 min and were subsequently washed in distilled water (Schroeder-Murphy et al., 1990). They were then put in Petri dishes with wet tissue paper in a growth chamber at $24^{\circ} \mathrm{C}$ during $2 \mathrm{~d}$. Pregerminated seeds were transplanted in PVC cylinders (height $22 \mathrm{~cm}$, internal diameter $10 \mathrm{~cm}$ ) and were grown in the glasshouse at $22.5^{\circ} \mathrm{C}$ with 13-h-photoperiod cycle during 18 days. A sample took from a silt-loamy soil and sieved through a $2 \mathrm{~mm}$ mesh (Typic Argiudol, Esperanza series) was used. Plants were watered with a nutritive solution (Hoagland and Arnon, 1950). Once the plants had the first trifoliated leaf fully expanded, the root systems were harvested and fixed in a solution of ascetic acid, formol, and alcohol (FAA) (Johansen, 1940) for $48 \mathrm{hs}$. They were subsequently conserved in alcohol at $70^{\circ}$ until they were analysed.

Three soil compaction levels were determined: 1.1, 1.3 and $1.5 \mathrm{~g} \mathrm{~cm}^{-3}$. Dry soil in each pot was weighted and changed accordingly so that they all reached these compaction levels. Loose soil was wetted with a spray to stimulate compaction. The volume of Hoagland solution employed was $15 \%$ of the dry weight of the soil used. The wetted soil fractions were subsequently put in plastic pots with a hydraulic press. Soil compaction occurred gradually at layers. Compaction pressures of $2,7.5$ and $14.0 \mathrm{MPa}$ were respectively determined for the $1.1,1.3$ and $1.5 \mathrm{~g} \mathrm{~cm}^{-3}$ treatments for homogeneous den- sification. The PVC cylinders were finally watered with Hoagland solution. The volume of Hoagland solution used freed $15 \%$ of the total porosity of compacted soil. In order to prevent nutritive solution from evaporating, the pots were protected with plastic bags, which had a small hole, thus allowing the stem to be uncovered. The plastic bags were removed daily during $30 \mathrm{~min}$ for airing. At the moment of transplant, unaltered soil samples were extracted from three pots of each compaction level using 7-cm-tall and 6-cm-in-diameter cylinders. Soil mechanical resistance was estimated on these samples using an electronic penetrometer with a cone top which was $4 \mathrm{~mm}$ in diameter (Tormena et al., 1999). Furthermore, the mechanical resistances measured $<0.1,0.5$ and 3.5 $\mathrm{MPa}$ were determined to correspond to the following compaction levels $1.1,1.3$ and $1.5 \mathrm{~g} \mathrm{~cm}^{-3}$, respectively. Three levels of soil mechanical resistance could thus be determined, namely: null (NR), low (LR), and high (HR). Plants grown at each compaction level are hereinafter referred to as NR plants, LR plants and HR plants.

For morphological studies, fixed roots were colored with a $0.1 \%$ neutral red solution (D'Ambrogio, 1986) and were digitalized with an "Image Pro-series" capture kit (from Media Cybernetics, USA). The distance from the apex to the first tertiary root $(\mathbf{L r})$ and the root diameter at $1.5 \mathrm{~cm}$ from the apex $(\mathrm{Dr})$ were measured on the secondary root apexes using an Image Pro Plus software. The coefficient corresponding to both variables was thus obtained. This coefficient is the form factor that indicates the number of times in which the first order root diameter is included in the root length (Nd1). Histological preparations were permanently made following Berlyn and Miksche (1976) to observe the root transverse section of the expansion area.

Data normality was verified for each variable and both variance analysis and Fisher test were carried out to estimate the statistical differences in the treatments. The statistical analysis was conducted using an InfoStad software.

\section{Results}

Soil mechanical resistance modified the shape of the root transverse section. In NR plants, the secondary root transverse section was circular, whereas in LR and HR plants, it was oval (Figure 1). However, the changes in shape in the HR plants were more marked as roots were found to have a ribbon-like shape (Figure $1 \mathrm{~F}$ ). The differences in shape in the transverse section of HR plants are associated with the cortex thickness. In this respect, no increase in the number of cortical cell files was observed in the widest area of the cortex. The cells located in the area of a largest diameter were found to expand, whereas those located in the sector of minimum diameter were found to be radially compressed. A similar phenomenon was observed in the transverse section of secondary roots of LR plants, although the changes in the cell shape of the cortical parenchyma were not as marked as those in HR plants. 
The geometrical dimensions of soybean root apexes underwent changes as a result of soil compaction (Table 1). Secondary root apex distance to the first tertiary root (Lr) decreased as soil mechanical resistance increased. The differences was found only in HR plants compared to NR and LR plants. In contrast, the diameter of secondary roots and the quotient of both variables $(\mathrm{Nd} 1)$ evidenced a positive relationship with the soil compaction level. The smallest diameter of secondary roots corresponded to NR plants. The mean value was $0.39 \mathrm{~mm}$. As to HR plants, Dr increased to $0.70 \mathrm{~mm}$, a significantly higher value than that corresponding to NR plants. Significant differences in $\mathrm{Lr}, \mathrm{Dr}$ and $\mathrm{Nd} 1$ were observed in HR plants with respect to NR and LR plants. $\mathrm{Dr}$ and $\mathrm{Nd} 1$ clearly showed the effect of soil mechanical impedance on root morphology.

Dispersion diagrams (Figure 2) show an inverse relationship between soil mechanical impedance and $\mathrm{Lr}$ and $\mathrm{Nd} 1$, and a direct relationship with Dr. Variables Nd1 and Dr proved to be the morphological characters that best evidenced the effect of soil compaction on roots. Table 2 shows, for each of the variables ana- lyzed in NR and LR plants, the probabilities of occurrence of Lr, Dr and Nd1 percentiles in HR plants, which are considered as limiting values to differentiate stressed roots from non-stressed ones. In the case of $\mathrm{Lr}$, and based on the percentile 90 of the highest impedance level $(43.2 \mathrm{~mm})$, results evidenced a probability of occurrence of $74 \%$ and $62 \%$ in NR and LR plants, respectively. The probability that $\mathrm{Dr}$ could be higher than the percentile value $10(0.47 \mathrm{~mm})$ was $21 \%$ and $42 \%$ for NR and LR plants, respectively. The probability that $\mathrm{Nd} 1$ could be lower than the percentile value 90 (63 $\mathrm{mm})$ was $4.3 \%$ and $7.3 \%$ for NR and LR plants, respectively.

Changes were also observed in the shape of rhizodermal cells. In HR plants, some hairs from the absorption area were found to have a bifurcation-like malformation in their apical sector. In addition, cells having external walls, which were either convex or papillose (Figure 3), were observed in the rhizodermis of the root hairs' zone. These cells, which were not yet fully trichoblasts, were found to be clearly differentiated from atrichoblasts.

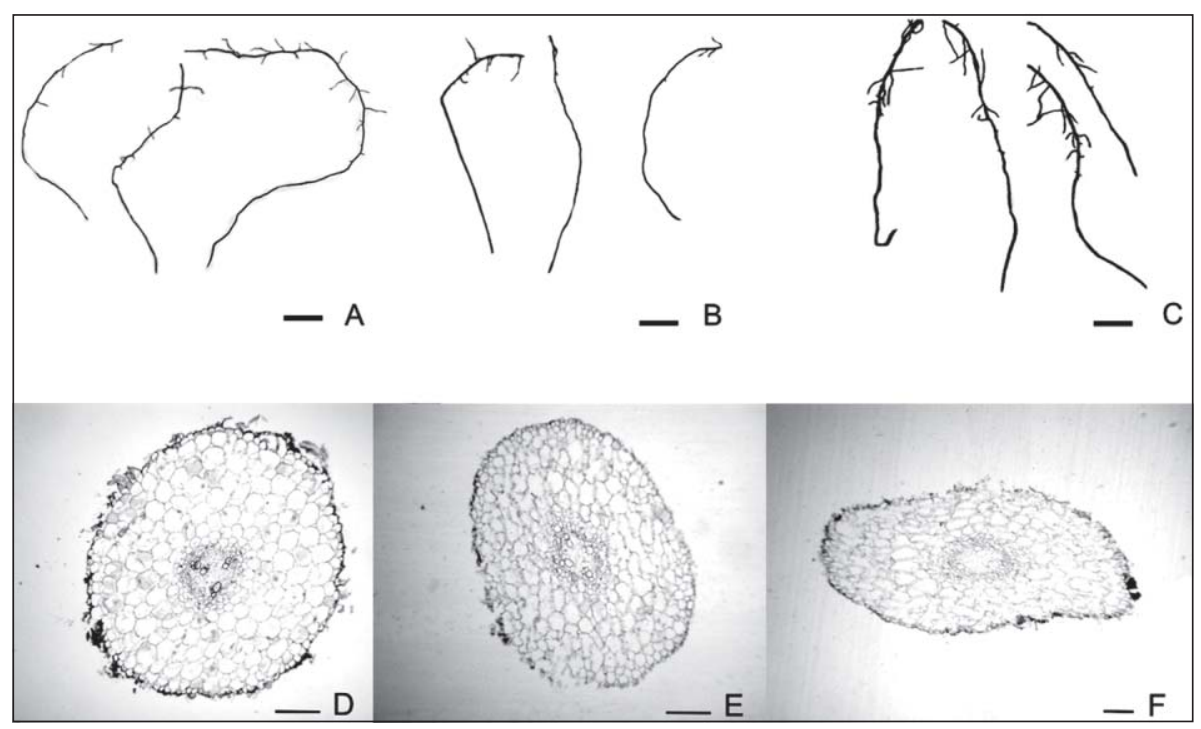

Figure 1 - A-C, Secondary roots. D-F, Transverse sections of soybean roots at $1.5 \mathrm{~cm}$ of the radical apex. A and D, < $0.1 \mathrm{MPa}$; B and E, $0.5 \mathrm{MPa}$ and $\mathrm{C}$ and F, 3.5 MPa. For A-C bar is $1 \mathrm{~cm}$. For D-F bar is $100 \mu \mathrm{m}$.

Table 1 - Root length and root diameter of secondary roots at different soil compaction levels. Sr: soil resistance; Lr: distance from the apex to the first tertiary root; Dr: diameter at $15 \mathrm{~mm}$ from the apex of secondary roots; Nd1: quotient between Lr and Dr; Sr: soil resistance.

\begin{tabular}{|c|c|c|c|c|c|c|c|c|c|}
\hline \multicolumn{2}{|c|}{ Soil mechanical impedance } & \multirow{2}{*}{\multicolumn{2}{|c|}{$\begin{array}{l}\text { Null } \\
<0.1\end{array}$}} & \multirow{2}{*}{\multicolumn{2}{|c|}{$\begin{array}{r}\text { Low } \\
0.5\end{array}$}} & \multirow{2}{*}{\multicolumn{2}{|c|}{$\begin{array}{c}\text { High } \\
3.5\end{array}$}} & \multirow{3}{*}{$\mathrm{F}$} & \multirow{3}{*}{$\mathrm{P}$} \\
\hline \multirow[t]{2}{*}{ Sr } & \multirow[t]{2}{*}{$\mathrm{MPa}$} & & & & & & & & \\
\hline & & $\mu$ & s.d. & $\mu$ & s.d. & $\mu$ & s.d. & & \\
\hline Dr & $(\mathrm{mm})$ & 0.39 & $0.04 \mathrm{a}$ & 0.45 & $0.08 \mathrm{a}$ & 0.71 & $0.12 \mathrm{~b}$ & 69.27 & $<0.0001$ \\
\hline $\operatorname{Lr}$ & $(\mathrm{mm})$ & 37.36 & $3.85 \mathrm{a}$ & 39.62 & $4.16 \mathrm{a}$ & 31.7 & $5.29 \mathrm{~b}$ & 88.35 & 0.0224 \\
\hline $\mathrm{Nd} 1$ & $(\mathrm{Lr} / \mathrm{Dr})$ & 96.53 & $8.13 \mathrm{a}$ & 89.96 & $8.35 \mathrm{a}$ & 46.87 & $9.43 \mathrm{~b}$ & 106.88 & $<0.0001$ \\
\hline
\end{tabular}

For a given variable, values followed by a same letter are not different $(p<0.05)$. 

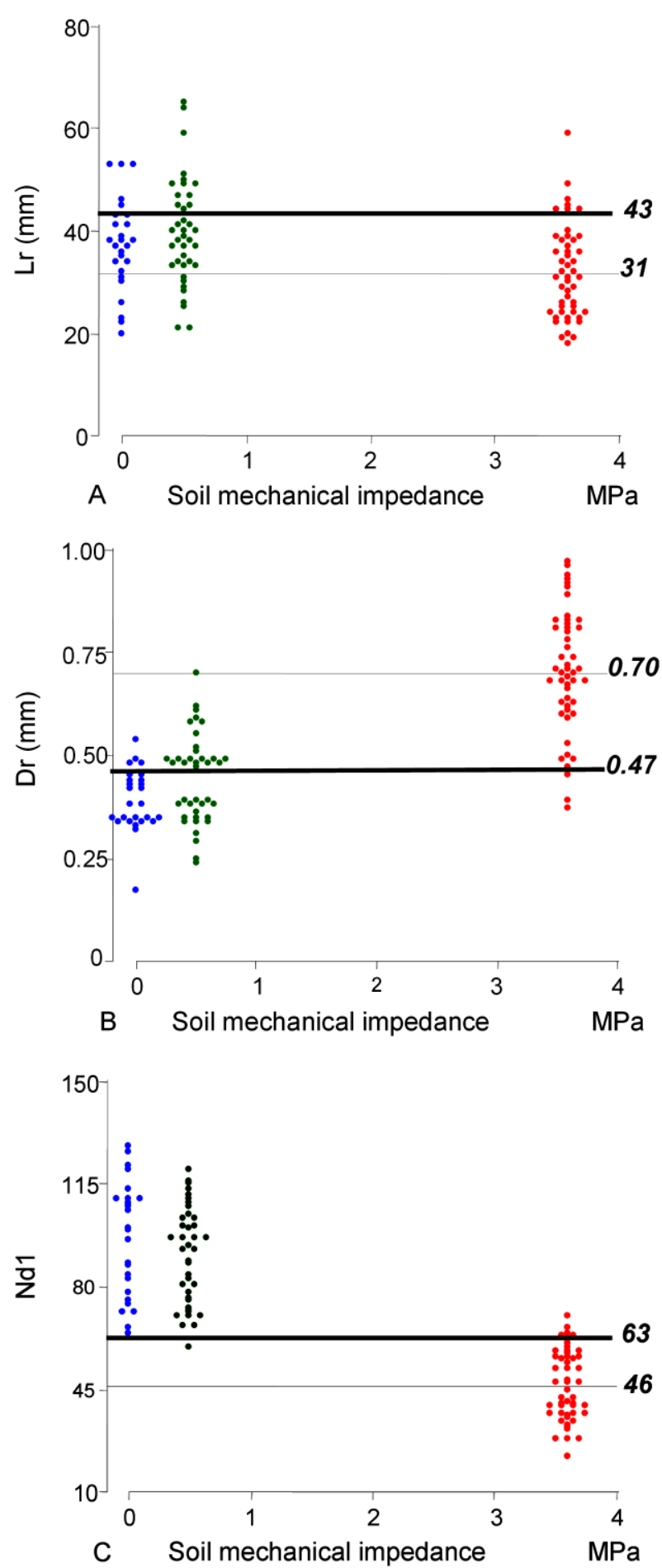

Figure 2 - A-C. Dot plot showing dispersion of morphological characters of soybean secondary root apexes as a function of soil mechanical impedance, null (blue): < $0.1 \mathrm{MPa}$; low (green): $0.5 \mathrm{Mpa}$; and high (red): 3.5 $\mathrm{MPa}$. Distance from the apex to the first tertiary root $(\mathrm{L})$, diameter at $15 \mathrm{~mm}$ from the apex (D) and quotient of both variables (Nd1). For the $3.5 \mathrm{MPa}$ treatment, cut lines indicate the significant average value of variables $(-)$ and the value corresponding to the percentile $90(-)$ for $\mathrm{Lr}$ and $\mathrm{Nd} 1$, and the percentile 10 for Dr.

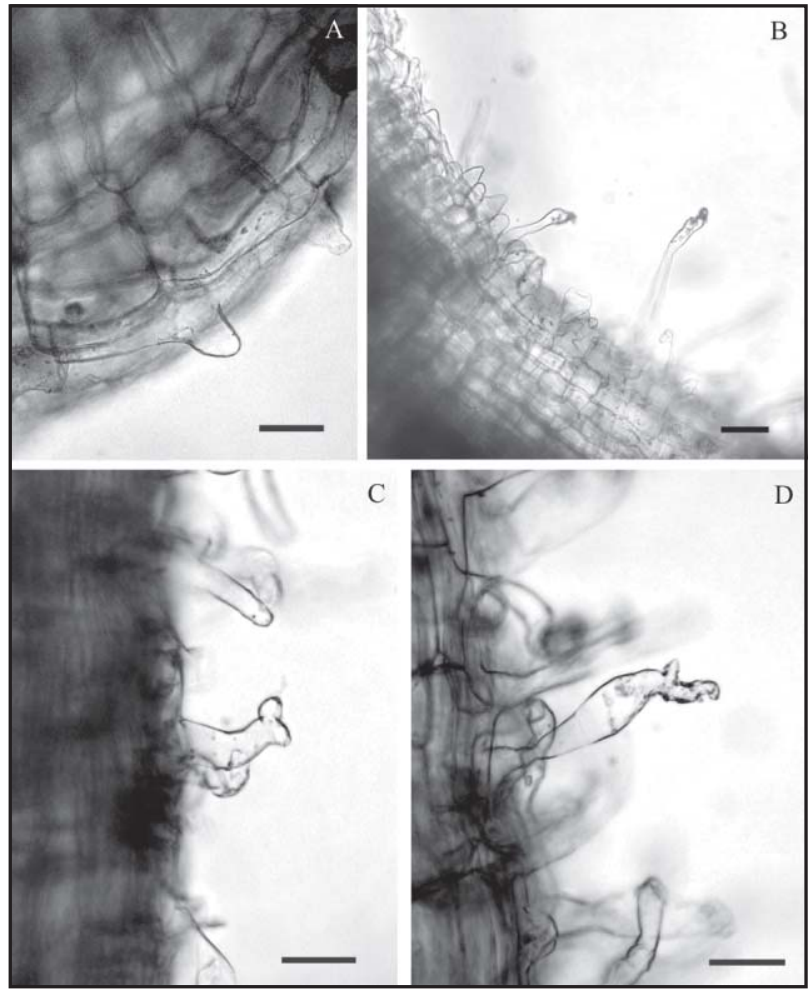

Figure 3 - Development of absorbent hairs in roots grown with $3.5 \mathrm{MPa}$ of mechanical resistence. A: apical growth in a trichoblast; $\mathrm{B}$ : absorbent hair and epidermal papilla-like cells; D and E: trichoblasts with apical malformation. Bar is $10 \mu \mathrm{m}$.

\section{Discussion}

The changes observed in roots in the present study as a result of soil compaction agree with previous findings (Bengough et al., 1993; Goodman and Ennos, 1999; Konôpka et al., 2009). In our research, the roots growing with $3.5 \mathrm{MPa}$ were found shorter and wider. However, Dr and Nd1 were found to be more sensitive to soil compaction. The values of $0.7 \mathrm{~mm}$ and 46 for Dr and Nd1, respectively, were good indicators of soil compaction. In addition, the values of $0.52 \mathrm{~mm}$ and 63 for $\mathrm{Dr}$ and $\mathrm{Nd} 1$, both corresponding to percentiles 0.1 and 0.9 , respectively, could be considered as a dividing line between compacted soils and those which are not. Furthermore, variable $\mathrm{Nd} 1$ is a useful tool not only to show ( $\mathrm{F}$ 106.88) differences among roots but also to clear distinguish roots growing in compacted soils from those growing in loose soils (4-7\%). On the other hand, $\mathrm{Nd} 1$ was estimated based on two morphological characteristics of roots. Thus, as edaphic factors may generate similar responses, the morphological characters of roots become very useful tools to easy identify different types of edaphic stress.

The oval-shaped tranverse section of roots in LR and HR plants is not associated with an increase in the number of the cortex cell files. In agreement with Atwell (1989; 1990), this section in LR and HR plants results 
Table 2 - Percentiles $(\mathrm{P})$ and probabilities of occurrence $(p)$ of the root length and root diameter of the secondary roots in soybean exposed to different levels of soil mechanical impedance: $\mathrm{P}_{10}$ : percentile 10 for root diameter (Dr) at $15 \mathrm{~mm}$ from the apex; $\mathrm{P}_{90}$ : percentile 90 for the distance of the apex to the first tertiary root $(\mathrm{Lr})$ and quotient of both variables (Nd1) in roots grown with $3.5 \mathrm{MPa}$ of soil mechanical resistance; $p$ : probabilities of occurrence of percentiles in plants grown at null and low soil compaction levels.

\begin{tabular}{|c|c|c|c|c|c|}
\hline Soil mechanical impedance & $\mathrm{P}$ & $p$ & $\mathrm{Lr}$ & Dr & $\mathrm{Nd} 1$ \\
\hline & & $\%$ & - & - & \\
\hline High (3.5 MPa) & $\mathrm{P}_{(10)}$ & - & - & 0.47 & - \\
\hline High (3.5 MPa) & $\mathrm{P}_{(90)}$ & - & 43.2 & - & 63 \\
\hline $\operatorname{Null}(<0.1 \mathrm{MPa})$ & - & $p\left(\mathrm{x} \geq \mathrm{P}_{(10)}\right)$ & - & 21 & - \\
\hline Null $(<0.1 \mathrm{MPa})$ & - & $p\left(\mathrm{x} \leq \mathrm{P}_{(90)}\right)$ & 74 & - & 4 \\
\hline Low (0.5 MPa) & - & $p\left(\mathrm{x} \geq \mathrm{P}_{(10)}\right)$ & - & 42 & - \\
\hline Low $(0.5 \mathrm{MPa})$ & - & $p\left(\mathrm{x} \leq \mathrm{P}_{(90)}\right)$ & 62 & - & 7 \\
\hline
\end{tabular}

from an increase in the diameter of the cortex cells in a radial direction (Croser et al., 1999; Bengough et al., 2006) (Figure 1). Baluška et al. (1995) claimed that the posmitotic isodiametric cell growth (PIG) region seems to be the site where radial widening of cortex cells occurs. However, this widening does not occur in all cells. Only the inner cortex cells are radially widened all along the largest root diameter, this being the reason why the transverse section of such roots is oval. This oval shape in roots could be due to the fact that the cell division does not occur in the PIG region (Ishikawa and Evans, 1993; Baluška, 1990; Baluška et al., 1995), and to the fact that the radial increase in cortical cells in more than one plane may induce the rupture of epidermis and outer cortex cells as a result of the tension produced by inner cortex cells.

The presence of soil planes with different mechanical resistances (Whiteley and Dexter, 1983) could be due to the formation of ribbon-like roots (Goodman and Ennos, 1999). Furthermore, animal and machinery trafficking as well as the way in which compaction levels were obtained in the present research all indicate that force direction applied to soil is vertical. This type of events produces a rearrangement of soil particles, which stimulates the development of a laminar structure. In addition, roots may find low resistance to grow horizontally but high resistance to grow vertically. Thus, vertically, soil behaves as a rigid environment, making roots grow with no malformations in the pores of either the same or larger diameter, whereas in those of smaller diameter cortex malformations could be produced (Scholefield and Hall, 1985) because these roots cannot overcome soil strength.

Developing roots are composed of tissues, which are different from each other in terms of i) polarity of their cellular constituents, ii) structure of their cell walls, and iii) physical tension pattern (Baluška et al., 1995). When tissue organs are formed under unfavourable environmental conditions, their shape is determined by the environmental factors intervening during their formation (Dolan and Davies, 2004).
The morphological changes in absorbent hairs observed in the present research (Figure 3) are not the same as those recorded by Alessa and Earnhart (2000). The presence of malformations in hairs and papilla-like cells seems to be related to changes in the cell cytoskeleton when these cells are under mechanical stress (Cleary and Hardham, 1993; Zandomeni and Schopfer, 1994; Hush and Overall, 1996).

\section{Conclusion}

The morphological characters of radical apexes are potential indicators of compact soil areas. Root diameter in expansion areas as well as the relationship between diameter and length from the apical apex to the point from which a lateral root grows, are the characters that, in fact, evidence highest sensitivity to soil compaction.

\section{References}

Alessa L.; Earnhart C.G. 2000. Effects of soil compaction on root and root hair morphology: implications for campsite rehabilitation. USDA Forest Service 5: 99-104.

Atwell, B.J. 1989. Physiological responses of lupin roots to soil compaction. p. 251-255. In: Loughman, B.C.; Gasparikova, O.; Kolek, J., eds. Structural and functional aspects of transport in roots. Kluwer Academic, Boston, MA, USA.

Atwell, B.J. 1990. The effect of soil compaction on wheat during early tillering. I. Growth development and root structure. New Phytologist 115: 29-35.

Baluška, F.; Hauskrecht, M.; Kubica, S. 1990. Posmitotic isodiametric cell growth in the maize root apex. Planta 81: 269274.

Baluška, F.; Barlow, P.W.; Kubica S. 1995 Importance of the posmitotic isodiametric growth (PIG) region for growth and development of roots. p. 41-51. In: Baluška, F.; Ėiamporová, M.; Gasparíková O.; Barlow, P.W., eds.. Proceedings of the Symposium on Structure and Function of Roots. Stará Lensna, Slovakia.

Beemster, G.; Masle, J. 1996. Effects of soli resistance to root penetration on leaf expansion in wheat (Triticum aestivum L.): composition, number and size of epidermal cells in mature blades. Journal of Experimental Botany 47: 16511662. 
Bengough, A.G.; Mackenzie, C.J.; Elangwe, H.E. 1993. Biophysics of the growth responses of pea roots to changes in penetration resistance. p.135-141. In: Baluška, F.; Èiamporová, M.; Gasparíková O.; Barlow, P.W., eds. Proceedings of the Symposium on Structure and Function of Roots. Stará Lensna, Slovakia.

Bengough, A.G.; Bransby, M.F.; Hans, J.; McKenna, S.J.; Roberts, T.J.; Valentine, T.A. 2006. Root responses to soil physical conditions; growth dynamics from field to cell. Journal of Experimental Botany 57: 437-447.

Berlyn, G.P.; Miksche P.1976. Botanical microtechnique and cytochemistry. Iowa State University Press, Ames, IA, USA.

Bingham, I.J.; Bengough. A.G. 2003. Morphological plasticity of wheat and barley roots in response to spatial variation in soil strength. Plant and soil 250: 273-282.

Cleary, A.L.; Hardham, A.R. 1993. Pressure induced reorientation of cortical microtubules in epidermal cells of Lolium rigidum leaves. Plant Cell Physiology 34: 1003-1008.

Clemson University. 2008. Rootfly: Version 1.8.25. Clemson University, Clemson, SC, USA.

Croser, C.; Bengough, A.G.; Pritchard, J. 1999. The effect of mechanical impedance on root growth in pea (Pisum sativum). I. Rates of cell flux, mitosis, and strain during recovery. Physiologia Plantarum 107: 277-286.

Croser, C.; Bengough, A.G.; Pritchard, J. 2000. The effect of mechanical impedance on root growth in pea (Pisum sativum). II. Cell expansion and wall rheology during recovery. Physiologia Plantarum 109: 150-159.

D'Ambrogio, A. 1986. Manual of Plan Histology Techniques. Hemisferio Sur, Buenos Aires, Argentina. (in Spanish).

Dardanelli, J.L.; Ritchie, J.T.; Calmon, M.; Andriani, J.M.; Collino, D.J. 2004. An empirical model for root water uptake. Field Crops Research 87: 59-71.

Dolan, L.; Davies, J. Cell expansion in roots. 2004. Current Opinion in Plant Biology 7: 33-39.

Goodman, A.M.; Ennos, A.R. 1999. The effects of soil bulk density on the morphology and anchorage mechanics of the root systems of sunflower and maize. Annals of Botany 83: 293-302.

Hoagland, D.R.; Arnon, D.I. 1950. The water culture method of growing plants without soil. California Agricultural Experiment Station Circular, Davis, CA, USA.

Hush, J.M.; Overall, R.L. 1996. Cortical microtubule reorientation in higher plants: dynamics and regulation. Journal of Microscopy 181: 129-139.
Ishikawa, H.; Evans, M.L. 1993. Induction of curvature in maize root by calcium or by thigmostimulation. Role of the posmitotic isodiametric growth zone. Plant Physiology 102: 1203-1210.

Johansen, D.A. 1940. Plant microtechnique. MacGraw-Hill, New York, NY, USA.

Kaspar, T.C.; Ewing, R.P. 1997. ROOTEDGE: software for measuring root length from desktop scanner images. Agronomy Journal 89: 932-940.

Konôpka, B.; Pagès, L.; Doussan, C. 2009. Soil compaction modifies morphological characteristics of seminal maize roots. Plant Soil Environment 55: 1-10.

Letey, J. 1985. Relationship between soil properties and crop production. Advances in Soil Science 1: 273-294.

Logdson, S.D.; Parker, J.C.; Reneau, R.B. 1987. Root growth as influenced by aggregate size. Plant and Soil 99: 267-275.

Lynch, J.P. 1995. Root architecture and plant productivity. Plant Physiology 109: 7-13.

Montagu, K.D.; Conroy, J.P.; Atwell, B.J. 2001. The position of localized soil compaction determines root and subsequent shoot growth responses. Journal of Experimental Botany 52: 2127-2133.

Regent Instruments. 2000. User Guide: Mac/WinRHIZO V4.1; Reference. Regent Instruments, Quebec, Canada.

Scholefield, D.; Hall, D.M. 1985. Constricted growth of grass roots through rigid pores. Plant and Soil 85: 153-162.

Schroeder-Murphy, S.L.; Huang, B.; King, R.L.; Smucker, A.J.M. 1990. Measurement of whole plant responses to compacted and flooded soil environments in the teaching laboratory. Journal of Agronomy Education 19: 171-175.

Tormena, C.A.; Silva, A.P.; Libardi, P.L. 1999. Soil physical quality of a Brazilian Oxisol under two tillage systems using the least limiting water range approach. Soil and Tillage Research 52: 223-232.

Whiteley, G.M.; Dexter, A.R. 1983. Behavior of root in cracks between soil peds. Plant and Soil 74: 153-162.

Young, I.M; Montagu, K.; Bengough, A.G. 1997. Mechanical impedance of root growth directly reduces leaf elongation rates of cereals. New Phytologist 135: 613-619.

Zadomeni, K.; Schopfer, P. 1994. Mechanosensory microtubule reorientation in the epidermis of maize coleoptiles subject to bending stress. Protoplasm 182: 96-101.

Received March 13, 2009

Accepted May 31, 2010 